\section{Cultural Landscape and Migration}

Gunnar Haaland

\section{Abstract}

This paper focus on the way Nepalese migrants in Myanmar use features of the natural environment in their homeland in metaphoric constructions of a cultural landscape expressing ethnic identity. It is through such "symbolic work" that perceptions of "ethnoscapes" are shaped and indoctrinated. Although the appeal is to symbols that can serve to foster the importance of Nepaliness as a basis for belonging to an imagined community, this does not mean that the caste/ethnicity interaction boundaries are broken down. It does mean however that sectors of activities where such boundaries are made relevant have been changed and so has the cultural content organized through such interaction boundaries. Ethnoscapes do not exist by themselves from a 'primordial' past; they require ongoing expression and confirmation. Features of a natural environment most migrants have never seen is used as sources for spinning compelling webs of significance extolling the values of belonging to a group that shares a common past in that environment. I shall here present material of an ethnoscape very different from what is experienced in Nepal, namely Nepalese multi-caste/ethnic communities among Kachins, Shans, Burmese, Indian and Chinese traders in the Kachin state of Northern Myanmar.

Keywords: Nepali migrants, Myanmar, ethnic identity, cultural landscape

"-place is selective for memories; that is to say, a given place will invite certain memories while discouraging others.... Memories are also selective for place; they seek out particular places as their natural habitats...places are congealed scenes for remembered contents; and as such they serve to situate what we remember" (Casey, 1987: 187).

\section{Introduction}

The natural environment is something that exists whether the viewer exists or not; landscape is what a viewer sees when looking at his/her surroundings. I find the distinction between environment and landscape useful because it directs our attention to the relationship between particular viewers and the conditions affecting the way they view their environment. The concept covers things that exist in the viewers' natural environment as well as in man-made modifications of that environment (e.g. material constructions, settlements, land-use features). However, what the viewer views is not a mirror reflections of what 'exists' in a "mindindependent" environment; what is viewed depend on the perspective of the viewer, e.g. botanical, geological, aesthetic, emotional, practical utility, symbols of group identity. Han Lorzing has expressed this point in the following way "I believe that 'landscape' is not just an isolated, objective thing in itself. To a large extent 'landscapes' are created by our perceptions. --landscape is a product of the human mind" (Lorzing, 2001:6). Landscapes are products of the mind that humans develop in their interaction with their environment.

Ingold has argued that knowledge "obtained through direct perception is thus practical, it is knowledge about what an environment offers for the pursuance of the action in which the perceiver is currently engaged. In other words, to perceive an object or event is to perceive what it affords. ---- the information picked up by an agent in the context of practical activity specifies what are called the 'affordances' of objects and events in the environment" (Ingold, 2007: 166). Learning to attend to components of practical utility in the environment is obviously of fundamental importance in peoples' acquisition of knowledge 
about the environment. However, they may view the environment from different perspective than the practical one of access to material satisfactions. Components in the natural environment may also constitute affordances for constructions of symbolic meanings. This is the theme of this paper and I shall explore it by analyzing case material showing how features of natural environment were used as sources for construction of symbolic meanings fostering ideas of belonging to a shared "imagined community" (Benedict Anderson, 1991) among migrants from a particular country.

In this connection I will draw on Arjun Appadurai's perspectives on the consequences of the migrations in the $20^{\text {th }}$ century for the practices of social anthropology. "The landscapes of group identity - the ethnoscapes - around the world are no longer familiar anthropological objects, insofar as groups are no longer territorialized, spatially bounded, historically unselfconscious, or culturally homogeneous” (Appadurai, 1991: 191).

\section{Landscape Construction among Nepalese Migrants to South-East Asia}

In various parts of South Asia and South-East Asia there are today a significant number of Nepalese communities. These migrants are composed of Nepalese from different caste background. They have come for different reasons and with different kinds of resources, and they have established themselves in different kinds of occupations.

When the British colonial power in 1884-85 conquered the Shans and the Kachins of Northern Myanmar they used their famous Nepalese Gurkha soldiers. After the conquest the British encouraged Nepalese Gurkhas to settle "--in the plains in order to bring the fertile area, now lying uncultivated, under the plough" (Hertz, 1960: 77). The Nepalese settlers became one of the pieces in the ethnic mosaic characteristic of the Kachin Hills.
Communities of Kachin and Shan identity constituted other pieces in the ethnic mosaic.

Ethnic groups do not exist by themselves from a primordial past; they require ongoing expression and confirmation. Past events and features of the natural environment in a remembered "homeland" may be sources for spinning of compelling webs of significance extolling the values of belonging to a group that shares that past and that nature. Typically such spinning takes the form of myths, songs, stories and other conventional forms of symbolic representation. However such cultural productivity may not be sufficient to maintain ethnic group identity in specific multi-ethnic and politico-economic contexts. The extent to which messages contained in particular symbolic representation catch among members of specific ethnic groups in ways that the members find convincing and compelling varies with contexts.

Here, I shall discuss how Nepalese popular song writer, Rocky Thapa, by using imagery of landscape features from Nepal contributed to forge an idea of belonging to an imagined Nepalese community different from other ethnic groups in Northern Myanmar. In his songs dominant idioms are derived from Nepalese nature, from Nepalese customs and from Nepalese history, i.e. idioms that may have an appeal to Nepalese irrespective of caste and ethnicity. Although the appeal is to symbols that can serve to foster the importance of Nepaliness as a basis for belonging to an imagined community, this does not mean that the caste/ethnicity interaction boundaries are broken down.

Rocky Thapa was a member of a band that performed at various functions. However, in those days they had very little idea about Nepalese music and culture, so the music and songs were mostly those learned from Hindi films. In 1957 a function was organized for foreign visitors in Myanmar. The Myanmar government had invited different ethnic groups of the country to present their folk music or dances that would represent aspects of their culture and 


\section{4 | Gunnar Haaland}

tradition. The Nepalese were also invited and Rocky Thapa and his group presented Hindi film songs and dances as Nepalese culture. One of the guests who were a British Gurkha major in the Myanmar army later spoke to Rocky Thapa and told him that he did not think that what they had performed was representative of Nepalese culture. Rocky Thapa was shaken by this comment and started to think about what cultural expressions could possibly represent Nepalese culture at such functions.

Initially this was very difficult because he was very much into Hindi film songs and dance, and so was the whole Nepalese population in Myanmar, but slowly with much hard work that he in his own words "started shedding off the 'Hindi' culture" and could begin writing "Nepalese folk songs".

Already in August b1957 Rocky wrote a song ("Look At Our Beautiful Nepali Costume”) bringing to the Myanmar Nepalese a vivid imagery of the beauty of the Nepal homeland and the traditional Nepalese costumes. This was the beginning of his career as a song writer and singer with a mission to revitalize the awareness among Myanmar Nepalese of their Nepali folklore, Nepalese language and customs; as well as introducing them to Nepalese literature and music as everyone in Myanmar was highly Indianised, listening to Hindi songs and watching Hindi films and had almost forgotten the Nepali music, language and culture.

In his opinion it took him about 20 years to finally get Nepalese people to accept what he called their traditional music. He considered his mission successful since he found that many people had been deleting their cassettes of Hindi songs by famous Indian singers like Mohammed Rafi and Mukesh and substituting them for copies of his own songs. Another song written after Rocky started his campaign to de-indianise Myanmar Nepalese was the one he presented when a Nepalese minister visited Myanmar in 1964.

\section{Nepali title: Phulera Phulyo Jhaka Ra Maka}

Phulerah phulyo jhaka ra maka suneli saipatri Bidesh bhari kasari chariyo yo phul yesari

Biruua hamro yo phul ramro namasau bideshma

Sunaulo rangale ranggai diula caadiko parbatma Sayapatri lakha lai jaula satha hridayma rakhera Amako sarir sringari diula yo phula gasera

Hami Nepali cha hamro desh himalko kakhaima

Ragat cha cokho Nepali ko yo hamro sarirma

Al-mali ajah jhamakkai sajha pardaicha bideshma

Yo phula oilhai jadaicha dajai laijau hai swadeshma

English translation: Flowers Have Blossomed Colourful And Bright

Marigold has blossomed everywhere with its golden hue How did this flower spread all over this foreign land?

Seed of this beautiful flower is ours,

Let it not disappear in this foreign land.

We will paint the silver Himalayas with golden hue,

Marigold in thousands, let us take them with us, keeping them in our hearts, And adorn our mother's body in garlands of marigold.

We, the Nepalis, have our homeland in the lap of the Himalayas And the pure blood of Nepalis run through our body; This day is ending and the darkness of night has reached this foreign land,This flower is withering, oh Brother! Let us take it back to our country.

A most important event occurred in 1970 when the Nepalese King Mahendra Bir Bikram Shah Dev during his visit to Myanmar came to Mandalay for three days. The Nepalese had organized a cultural function in Maymyo where Rocky presented a cultural programme 
Dhaulagiri Journal of Sociology and Anthropology Vol. 4, 2010 | 105

and sang a song he had written "Surya Ko Jyoti Candra Ko Chaya"

\section{Nepali title: SuryaKo Jyoti Candrako Chaya}

Surya ko jyoti candrako chhaya parena

hami mathi

Phakrena kahile hamro lali Gurans Lalupate.

Dukhako bhari bisauna bhani ayethe Nepali,

Bharile thici kamale mici yehinai bilaye

Phailai biruua car disha tira dara ra kara mathi

Tuhura bhai ekalai basetapani pirenau kasai lai,

Chharenau hami boli ra bhasa purkheuli riti lai

Lukeko chhaina chhau hami pani yahi dharti mata mathi.

Hamkai deula himale batas kahile ho hami lai

Swarganai chhune Sagarmatha dekhenau hami lai

ekahi mulko pani hau hami pani rakha ajuli mathi.

\section{English title: Light of the Sun and shade of the Moon.}

Light of the sun and shade of the moon did not reach us,Nor did the Gurans and Lalupate bloom for us.

Came the Nepalese seeking to relieve themselves of their hardship and pain, But pressed by the heavy burden and crushed by endless work, they disappeared in this land.

\section{Orphaned as we were and living in loneliness}

We never did torment anyone, nor did we forget our language, custom or tradition, out of sight, we were not, but very much alive on this very earth.

When will the Himalayan breeze blow for us?

And when will the mighty Everest almost touching heaven ever see us? We are the water of the same source, please take us in your fold.

\section{6 | Gunnar Haaland}

\section{Natural Metaphors and Group Identity}

In these songs Rocky explicitly plays on metaphors that express a condition of Diaspora among the Nepali settlers in Myanmar. That condition only exists as long as people are aware of being away from a "homeland". This awareness was according to Rocky being weakened among the Nepalese in Myanmar, and he himself had a "religious' like awakening to the awareness of the importance of belonging to a larger imagined community consisting of people of "his kind" in a country he had never seen, namely Nepal. He saw it as his mission to make other Nepalese in Myanmar aware of belonging to that community.

In his song "Flowers Have Blossomed Colourful And Bright", Rocky draws on the powerful imagery of the marigold (in Nepali "sayapatri" literally meaning "hundreds of petals"). The marigold with its golden petals is a flower that is closely associated with Nepaliness in the sense that Nepalese cultivate it in their gardens for use as garlands and in the decoration of their houses during the important festivals of Tihar (festival of lights) and Dasain (Festival of the Goddess Durga) in autumn. In his song Rocky describes it with reference to its golden hue - an attribute associated with gold, i.e. the natural element that par excellence stands for purity. The flower is clearly meant to serve as a marker of Nepali identity. This associative linkage is developed further in the second line of the song where Rocky raises the question about how the marigold comes to be spread to a land that is foreign to the homeland of the flower. He answers the question by associating the seeds of the marigold with the seeds of the Nepalese people - the reproduction of the marigold depends on the Nepalese tending it, and the reproduction of the Nepalese depend on them being faithful to their Nepali "culture" (marigold serving as a metonym for Nepali "culture"). If marigold disappears, Nepalese identity will disappear. The longing for return to the home country is expressed in several metaphors: "painting the silver Himalayas with golden hue, i.e. bringing the seeds of the marigold (Nepalese in Diaspora) back to Nepal; marigold (i.e. Nepaliness) in the hearts; mother's body 
(motherland) adorned with marigold (filling Nepal with Diaspora Nepalese)." By using Himalayas as a metonym for the Nepalese homeland, the ideal of Nepaliness is dressed up in a garb of sacred associations with the great civilizations of Hinduism and Buddhism; by talking of the purity of Nepali blood the importance of Nepali endogamy in relation to other groups in Myanmar is over-communicated, while endogamy within the different Nepali castes is under-communicated; in the foreign land night has reached, i.e. the restrictions imposed on Nepalese and other foreigners after Ne Win's coup in 1962 caused the marigold to wither and it is time to return to the homeland.

In the song presented for King Mahendra the Diaspora condition is expressed in the idiom of being orphaned. Rocky compares Nepalese in Myanmar to orphans who are denied normal human care and support (expressed in the metaphors of the life-giving light of the sun, and the soothing shelter of the moon), as well as enjoyment of the sight of emblems of national identity (the national flowers of Nepal - Gurans i.e. Rhododendron and Lalupate i.e. Poinsettia). In this harsh situation they are threatened by disappearance although they have not forgotten their language and traditions

It does not take much imagination to make the metaphoric connection between Mount Everest almost touching heaven and King Mahendra as the ruler of the Himalyan Kingdom. The appeal to the King to see that the Nepalese in Myanmar are from the same source as the Nepalese in Nepal is rather direct, and so is the request to bring them back to their motherland.

\section{Conclusion}

As anthropologists we have one foot in the study of the cultural particularities in terms of which concrete individuals conceptualise and evaluate events in the world they live in, and one foot in the study of social and ecological interdependencies which emerge in

\section{8 | Gunnar Haaland}

people's interaction, no matter whether these interdependencies are known to the interacting people or not. (See Rappaport, 1994).

On the one hand to quote Clifford Geertz we believe "with Max Weber, that man is an animal suspended in webs of significance he himself has spun, I take culture to be those webs" (Geertz, 1973: 5). A fundamental anthropological task is to uncover this "finite segment of the meaningless infinity of the world process, a segment on which human beings confer meaning and significance" (Weber, 1949: 81). Individual human beings can only act in the world if they have been able to spin a web of significance that provide them with workable mental "maps" of their social and natural environment and workable ideas about how to act in that world. We don't spin these webs from scratch, but from spinning techniques and styles that we have been exposed to.

In his songs, Rocky spins webs of significance from items and symbolic patterns sufficiently familiar to the Myanmar Nepalese, i.e. ideas and values associated with items like marigold, rhododendron, poinsettia, the snow capped peaks of the Himalayas, Nepali costumes etc. However, the pattern he spins is not just a copy of these ideas and values, but he draws on them to construct new ways of conceiving their life in Myanmar as a Diaspora situation. In his songs he actively tries to create a collective memory, or myth, about their place of origin as an ideal home to which he encourages them to return. Migration in itself is not a sufficient condition for the creation of a Diaspora consciousness, such consciousness has to be expressed in objectified symbolic forms and subjectively internalised, i.e. the webs of significance objectified in symbolic forms in the songs have to be reproduced in the webs people subjectively spin in their mind for understanding their world and acting in it.

In his search for unifying signs Rocky tries to clothe Nepalese identity in features that the outside world admires and associates with Nepal, as well as in features that may resonate with the emotions of the Nepalese. The majestic beauty of the Himalayas is a very good idiom because it is not only admired in the world at 
large, but it is also loaded with specific sacred meanings for all Nepalese, and as we have seen Rocky makes a lot out of it. Rocky is one of the actors who through his cultural creativity served to create a particular landscape of Nepalese group identity in a particular place, namely Myanmar. This ethnoscape is however not spatially bounded, although it is anchored in an imagined diasporic consciousness connecting it to a specific motherland, Nepal. A certain amount of shared cultural understandings are forged between Nepalese particularly with regard to what they have in common in contrast to their Burmese neighbours. However, this did not imply that all Myanmar Nepalese were becoming culturally homogeneous. James Clifford has argued that "-contemporary diasporic practices cannot be reduced to epiphenomena of nationstate or of global capitalism" (Clifford, 1994: 302). I have tried to show how nation-states (Nepal and Myanmar) and globalisation processes (politico-military expansion and the impact of international economic exchanges) constitute important contexts for the particular form of diaspora discourse a gifted Nepali singer articulated. However, the symbolic forms in which it was articulated cannot be reduced to nation-states and globalisation, and they do not seem to evoke much enthusiasm among the many Myanmar Nepalese who have migrated to Thailand and carved out highly profitable economic niches particularly in the garment trade in tourist resorts.

The memories of the homeland did not have much significance until the politico-economic situation changed in Myanmar and Rocky Thapa started his "memory work" (Litzinger, 1998). Alienation from the host-country became important in Myanmar after Ne Win's coup, while it is not so in Thailand. (Haaland, 2008).

\section{References}

Anderson, B. (1991). Imagined Communities: Reflections on the Origin and Spread of Nationalism (rev. ed.). London: Verso.

Appadurai, A. (1991). Global Ethnoscapes: Notes and Queries for a Transnational Anthropology. In Recapturing Anthropology (ed. R. Fox). Santa Fe. New Mexico: School of American Research Press.

Casey, E. S. (1987). Remembering: A phenomenological study. Bloomington: Indiana University Press.

Clifford, J. (1994). Diasporas. Cultural Anthropology. Vol. 9, no 3

Geertz, C. (1973). Thick Description: Toward an Interpretive Theory of Culture. In The Interpretation of Cultures. (ed. C. Geertz) London. Fontana Press.

Haaland, G. (2008). Explaining causes in evolving contexts: From Nepali hill Farmers to Business Managers in Thailand. I: Against the Grain. The Vayda Tradition in Human Ecology and Ecological Anthropology. (eds: B.B.Walters, B.J. McCay P. West, S. Lees) Lanham. AltaMira Press.

Hertz, H. F. (1960). Burma Gazetteer, Myitkyina District, Vol A. Rangoon: Superintendent, Govt. Printing and Staty, Union of Burma.

Ingold, T. (2007). The Perception of the Environment. Essays in Livelihood, Dwelling and skill. London: Routledge.

Litzinger, R. (1998). Memory Work: Reconstituting the Ethnic in Post-Mao China. Cultural Anthropology Vol 13 No 2

Lorzing, H. (2001). The Nature of Landscape. A personal Quest. Uitgevirij. Holland.

Rappaport, R. A. (1973). Ecology, Meaning, and Religion. Richmond CA North Atlantic Books.

Weber, M. (1949). The Methodology of the Social Sciences. Translated and Edited by Shils, E.E. and Finch, H. A. New York: Free Press. 